\title{
Genetic analysis of the vitamin $D$ receptor gene in two epithelial cancers: melanoma and breast cancer case-control studies Eva Barroso $^{\dagger 1}$, Lara P Fernandez ${ }^{\dagger 1}$, Roger L Milne ${ }^{2}$, Guillermo Pita ${ }^{3}$, Elena Sendagorta ${ }^{4}$, Uxua Floristan ${ }^{4}$, Marta Feito ${ }^{4}$, Jose A Aviles ${ }^{5}$, Manuel Martin-Gonzalez ${ }^{6}$, Jose I Arias7 , Pilar Zamora7 , Monserrat Blanco ${ }^{8}$, Pablo Lazaro ${ }^{5}$, Javier Benitez ${ }^{1,3}$ and Gloria Ribas*1
}

\begin{abstract}
Address: ${ }^{1}$ Human Genetics Group; Human Cancer Genetics Program, Spanish National Cancer Research Centre (CNIO), Madrid, Spain, ${ }^{2}$ Genetic and Molecular Epidemiology Group; Human Cancer Genetics Program, CNIO, Madrid, Spain, ${ }^{3}$ National Genotyping Centre (CeGen), Human Cancer Genetics Program, CNIO, Madrid, Spain, ${ }^{4}$ Department of Dermatology, La Paz Hospital, Madrid, Spain, ${ }^{5}$ Department of Dermatology, Gregorio Marañon Hospital, Madrid, Spain, ${ }^{6}$ Department of Dermatology, Ramon y Cajal Hospital, Madrid, Spain, ${ }^{7}$ Service of Surgery, Monte Naranco, Oviedo, Spain and ${ }^{8}$ Department of Oncology, La Paz Hospital, Madrid, Spain

Email: Eva Barroso - eva.barroso@salud.madrid.org; Lara P Fernandez - lpfernandez@cnio.es; Roger L Milne - rlmilne@cnio.es; Guillermo Pita - gpita@cnio.es; Elena Sendagorta - elenasendagorta@hotmail.com; Uxua Floristan - uxuafloristan@hotmail.com; Marta Feito - marta8marta@hotmail.com; Jose A Aviles - jaavilesizquierdo@gmail.com; Manuel Martin-Gonzalez - martingolez@yahoo.es; Jose I Arias - joseignacio.arias@sespa.princast.es; Pilar Zamora - pzamora.hulp@salud.madrid.org;

Monserrat Blanco - montseblancocodesido@yahoo.es; Pablo Lazaro - plazaroo@meditex.es; Javier Benitez - jbenitez@cnio.es; Gloria Ribas* - gribas@cnio.es

* Corresponding author †Equal contributors
\end{abstract}

Published: 23 December 2008

BMC Cancer 2008, 8:385 doi:10.1 |86/|47|-2407-8-385
Received: 16 October 2008

Accepted: 23 December 2008

This article is available from: http://www.biomedcentral.com/ |47|-2407/8/385

(C) 2008 Barroso et al; licensee BioMed Central Ltd.

This is an Open Access article distributed under the terms of the Creative Commons Attribution License (http://creativecommons.org/licenses/by/2.0), which permits unrestricted use, distribution, and reproduction in any medium, provided the original work is properly cited.

\begin{abstract}
Background: Vitamin D serum levels have been found to be related to sun exposure and diet, together with cell differentiation, growth control and consequently, cancer risk. Vitamin D receptor (VDR) genotypes may influence cancer risk; however, no epidemiological studies in sporadic breast cancer (BC) or malignant melanoma (MM) have been performed in a southern European population. In this study, the VDR gene has been evaluated in two epithelial cancers $B C$ and MM.
\end{abstract}

Methods: We have conducted an analysis in 549 consecutive and non-related sporadic BC cases and 556 controls, all from the Spanish population, and 283 MM cases and 245 controls. Genotyping analyses were carried out on four putatively functional SNPs within the VDR gene.

Results: An association with the minor allele A of the non-synonymous SNP rs2228570 (rs I07358I0, Fokl, Met IThr) was observed for $B C$, with an estimated odds ratio $(O R)$ of $1.26(95 \% \mathrm{Cl}=1.02-1.57 ; p=0.036)$. The synonymous variant rs73 1236 (Taql) appeared to be associated with protection from $\mathrm{BC}(\mathrm{OR}=0.80,95 \% \mathrm{Cl}=0.64-0.99 ; \mathrm{P}=0.047)$. No statistically significant associations with MM were observed for any SNP. Nevertheless, sub-group analyses revealed an association between $r s 2228570$ (Fokl) and absence of childhood sunburns ( $O R=0.65, p=0.003$ ), between the 3'utr SNP rs739837 $(B g l l)$ and fair skin $(O R=I .3 I, P=0.048)$, and between the promoter SNP rs45I6035 and the more aggressive tumour location in head-neck and trunk $(O R=I .54, p=0.020)$.

Conclusion: In summary, we observed associations between SNPs in the VDR gene and BC risk, and a comprehensive analysis using clinical and tumour characteristics as outcome variables has revealed potential associations with MM. These associations required confirmation in independent studies. 


\section{Background}

The vitamin $\mathrm{D}$ metabolite $1 \alpha, 25$-dihydroxivitamin $\mathrm{D}_{3}$ $(1,25 \mathrm{D}$, also known as calcitriol) is the biologically active form of vitamin $D_{3}[1]$. The concentration of vitamin $D_{3}$ in natural foods is quite low, and the majority of vitamin $\mathrm{D}_{3}$ in individuals is from cholesterol metabolites in the skin upon exposure to ultraviolet (UV) radiation. 1,25D modulates the expression of specific genes in a tissue-specific manner by binding to the nuclear vitamin $D$ receptor $(V D R)$ and to specific DNA vitamin D response elements. The receptor and ligand induce a program of gene expression that contributes to the maintenance of the quiescent, differentiated phenotype. They are therefore able to regulate cellular proliferation, apoptosis and differentiation in many cell types [2].

Recent epidemiological studies have shown an association between low serum 1,25D levels and increased risk of breast, colorectal and prostate cancers. Furthermore, several studies have reported a possible link between polymorphic variants in the vitamin $\mathrm{D}$ receptor gene and increased susceptibility for primary and metastatic breast cancer, squamous cell carcinoma, colorectal cancer and prostate cancer [3-6]. Although the functional significance of these polymorphic variants remains unknown, there is strong evidence suggesting that they may have functional consequences in epithelial carcinogenesis and tumour progression $[7,8]$. VDR polymorphisms have been widely studied in Caucasian populations in relation to breast cancer (BC) [9-11] and malignant melanoma (MM) susceptibility $[12,13]$, each finding different effects for SNPs, depending on the population analyzed and environmental factors acting upon them.

It is of general interest to study the most characterised variants in VDR in southern European countries, where sun exposure is typically higher than in northern European countries (maximum UV Index during the summer months $=9$ in Spain versus 6.5 in Netherlands) $[14,15]$ In this study, we investigated for the first time the role of polymorphisms in VDR in two epithelial cancers, sporadic BC and MM, in the Spanish population. Additionally, clinical and tumour phenotypic variables have been taken into account to better define the involvement of $V D R$ in these pathologies.

\section{Methods}

\section{Study Subjects, Data Collection and DNA Extraction} BC Study

The BC case-control study included a total of 549 consecutive and non-related sporadic BC cases and 556 control women. Cases were recruited from $1^{\text {st }}$ January 2002 to $31^{\text {st }}$ December 2006 from three Spanish public hospitals: 258 (47\%) from Monte Naranco Hospital, in Oviedo; 155 (28\%) from the Fundación Jiménez Díaz, and 136 (25\%) from La Paz University Hospital, both in Madrid. Con- trols were unaffected Spanish women, recruited at three centres in Madrid: 455 (82\%) from the Menopause Research Centre at the Instituto Palacios, $82(15 \%)$ from the Fundación Jiménez Díaz, and 19 (3\%) from the Madrid College of Lawyers. All cases and controls were women and controls were selected so that their age range was comparable to that of cases. We could not frequency match due to the larger numbers of cases.

Information about personal characteristics of cases and controls (age at diagnosis for cases or age at blood sample collection for controls, age at menarche, parity and menopausal status), and clinical and tumour characteristics for cases (metastasis at diagnosis, tumour grade, type and size, nodal involvement, and immunohistochemical markers), was either collected by the treating physician or extracted by review of medical records. This information is summarised in Additional file 1.

\section{Study}

The MM case-control study was based on 283 consecutive and non-related sporadic MM cases that were recruited from $1^{\text {st }}$ September 2004 to $15^{\text {th }}$ March 2008, at the Departments of Dermatology of three hospitals in Madrid: 147 (52\%) from Gregorio Marañón General University Hospital, 54 (19\%) from La Paz University Hospital and 82 (29\%) from Ramón y Cajal University Hospital. A total of 245 cancer-free controls, frequency matched to cases by sex and age in ten-year categories, were recruited from the Madrid College of Lawyers (218 participants, 89\%) and from Gregorio Marañón General University Hospital (27 participants, 11\%).

A standardised questionnaire was used to collect information on pigmentation characteristics (eye colour, hair colour, skin colour, number of nevi, presence of solar lentigines), the presence of childhood sunburns, Fitzpatrick's classification of skin type, tumour location, Breslow index (deep index), and personal and family history of cancer, as described previously $[16,17]$ (see Additional file 2). Fitzpatrick's classification of skin type was assessed for cases only, by review of medical records.

All participants in both studies were Caucasian and of Spanish origin. All subjects gave informed consent and the $\mathrm{BC}$ and $\mathrm{MM}$ studies were approved by the Ethics Committees of La Paz University Hospital and Gregorio Marañón General University Hospital, respectively.

Genomic DNA from cases and controls was extracted using the MagNA Pure LC Instrument according to the manufacturer's protocol as previously described $[16,18,19]$.

\section{SNP selection}

Three public databases were used to collect information about SNPs in VDR: NCBI http://www.ncbi.nlm.nih.gov, 
Ensembl http://www.ensembl.org, and HapMap http:// www.hapmap.org. Four SNPs were considered for inclusion because they have been widely analysed in previous epidemiological studies. All had minor allele frequency (MAF) greater than or equal to $10 \%$. Two are located on exons, one is in the putative promoter region and the other in the 3'utr region. The two coding SNPs selected have been reported to be associated with breast cancer, in previous studies [11,20,21].

\section{Genotyping assays}

Genotyping was carried out using the TaqMan platform following the manufacturer's instructions. SNPs assays were designed using Applied Biosystems Assay-by-Design and Assay-on-Demand probes (Applied Biosystems, Foster City, CA, USA) (provided upon request). The genotype of each sample was automatically determined by measuring final allele-specific fluorescence in the ABI Prism 7900HT Detection System, using the SDS 2.1 software for allele discrimination (Applied Biosystems, Foster city, USA).

As a quality control measure, we included at least 2 sample duplicates and 1 non-template sample per 96-well plate. Genotypes were scored by two different personnel in the laboratory. We obtained a concordance rate of $100 \%$ for all four SNPs studied.

\section{Statistical Analysis}

For all polymorphisms studied, Fisher's exact test was used both to test for deviations from Hardy-Weinberg equilibrium (HWE) among controls and to compare differences in the MAF distributions between cases and controls.

In order to assess associations between genotypes, haplotypes and cancer risk, several analyses were performed. Genotype-related odds ratios (ORs), their corresponding 95\% confidence intervals (CIs) and associated p-values were estimated via unconditional logistic regression. This was done for each of heterozygotes and minor-allele homozygotes relative to common-allele homozygotes, as well as under an additive model, in the latter case estimating an effect per copy of the minor allele carried. Known or suspected risk factors for BC (age, number of live births, age at menarche, and menopause status) and MM (eye colour, hair colour, skin colour, number of nevi, lentigines, and childhood sunburns) were evaluated for potential confounding effects by including them in multivariate analyses.

Associations between VDR polymorphisms genotyped and various individual, clinical and tumour characteristics were assessed via logistic regression in order to determine their potential modifying effects on BC and MM risk. This was done for cases and controls pooled for each variable. Eye colour (blue/green versus brown), hair colour (blond/ red versus brown/black), skin colour (fair versus brown), number of nevi ( $=50$ versus $<50)$, presence of lentigines (yes versus no) and childhood sunburn (yes versus no) were used as the outcome variables for MM.

Among $\mathrm{BC}$ cases only, the presence of metastastic disease at diagnosis (yes versus no), tumour histology (invasive versus in situ), tumour grade (grade $>1$ versus grade 1 ), tumour size $(>2 \mathrm{~cm}$ versus $=2 \mathrm{~cm})$, nodal involvement (yes versus no), estrogen receptor status (positive versus negative) and progesterone receptor status (positive versus negative), were used in the analysis. For MM casesonly analyses, the prior diagnosis of MM (yes versus no), phototype (I/II versus III/IV), tumour location (head/ neck/trunk versus extremities) and tumour depth (T2/T3/ $\mathrm{T} 4$ versus $\mathrm{T} 0 / \mathrm{T} 1$ ) were considered as the outcome variables.

SPSS v11.0 was used to carry out these analyses. All p-values were two-sided and those less than 0.05 were considered statistically significant

\section{Results and Discussion Associations of VDR rs73 I 276 and rs2228570 polymorphisms with cancer risk}

Allelic frequencies for each SNP and the p-value for their comparison between cases and controls are presented in Table 1. We found no evidence of departure from HardyWeinberg equilibrium for any of the four SNPs genotyped (all p-values > 0.05). Results from univariate and multivariate genotype analysis are shown in Table 2.

We observed evidence of differences in minor allele frequency (MAF) between BC cases and controls for the synonymous change rs731236 (TaqI) $(\mathrm{p}=0.028)$. The estimated OR per minor allele (C) in this SNP was 0.84 (95\%CI 0.71-0.99, $\mathrm{p}=0.034$ ). This per-allele OR estimate was not substantially different in the multivariate analysis adjusting for age, number of live births, age at menarche, and menopause status (OR per allele $=0.85$, 95\% CI 0.69-1.03, $\mathrm{p}=0.102)$. Regarding the SNP rs2228570 (FokI) (Met1Thr, formerly known as rs10735810), weak evidence of differences in MAF between BC cases and controls was observed $(p=0.080)$. The estimated OR per minor allele in this SNP was 1.17 (95\%CI 0.98-1.40, $\mathrm{p}=0.081$ ), whereas the per-allele OR estimated in the multivariate analysis adjusting for potential confounding factors was higher, and statistically significant $($ OR per allele $=1.26,95 \%$ CI $1.02-1.57, \mathrm{p}=$ $0.036)$.

In general, previous studies have found no evidence of association with BC for rs731236 (TaqI) and rs2228570 
Table I: Allelic frequencies comparison between cases and controls in the four SNPs tested, in both BC and MM pathologies

\begin{tabular}{|c|c|c|c|c|c|c|c|c|c|c|}
\hline \multirow[b]{3}{*}{ SNP ID } & \multirow{3}{*}{$\begin{array}{l}\text { Other } \\
\text { names }\end{array}$} & \multirow{3}{*}{$\begin{array}{c}\text { SNP } \\
\text { Location }\end{array}$} & \multirow{3}{*}{$\begin{array}{c}\text { Nucleotide } \\
\text { Change* }\end{array}$} & \multicolumn{3}{|c|}{ BREAST CANCER } & \multicolumn{3}{|c|}{ MELANOMA } & \multirow{3}{*}{$\begin{array}{c}\text { HapMap } \\
\text { Caucasian } \\
\text { MAF }\end{array}$} \\
\hline & & & & $\begin{array}{c}\text { Cases } \\
(\mathbf{N}=\mathbf{5 4 9})\end{array}$ & $\begin{array}{l}\text { Controls } \\
(N=556)\end{array}$ & & $\begin{array}{c}\text { Cases } \\
(\mathbf{N}=\mathbf{2 8 3})\end{array}$ & $\begin{array}{l}\text { Controls } \\
(N=245)\end{array}$ & & \\
\hline & & & & MAF & MAF & p-value ${ }^{++}$ & MAF & MAF & p-value ${ }^{++}$ & \\
\hline rs45I6035 & & $5^{\prime}$ upstrem & $\mathrm{T}>\mathrm{C}$ & 0.41 & 0.39 & 0.27 & 0.44 & 0.40 & 0.28 & 0.45 \\
\hline rs2228570 & $\begin{array}{c}\text { Fokl. } \\
\text { rs } 10735810\end{array}$ & MetIThr & $G>A$ & 0.37 & 0.34 & 0.08 & 0.31 & 0.33 & 0.33 & 0.44 \\
\hline rs731236 & Taql & Ile352 & $\mathrm{T}>\mathrm{C}$ & 0.38 & 0.43 & 0.028 & 0.41 & 0.39 & 0.50 & 0.44 \\
\hline rs739837 & Bgll & $3^{\prime}$ utr & $\mathrm{T}>\mathrm{G}$ & 0.46 & 0.46 & 0.90 & 0.47 & 0.50 & 0.74 & 0.43 \\
\hline
\end{tabular}

MAF, Minor Allele Frequency.

Statistically significant results $(p<0.05)$ indicated in bold.

* Correspondence of nomenclature of SNP alleles are as following: the Fokl alleles G and A correspond to F and $\mathrm{f}$, respectively; the Taql alleles T and C correspond to $\mathrm{T}$ and $\mathrm{t}$, respectively; and $\mathrm{Bgll}$ alleles $\mathrm{T}$ and $\mathrm{G}$ correspond to $\mathrm{B}$ and $\mathrm{b}$, respectively.

${ }^{++} \mathrm{p}$-value, difference of MAF between cases and controls.

(FokI) [9,11,22-27]. All of these studies had limited statistical power to detect a moderate association. Population stratification may be another explanation for the lack of consistency in results. However, two studies with marginal statistically significant results for rs731236 (TaqI) reported contradictory results $[11,24]$, whereas studies using larger sample sizes from Caucasian populations have shown risk effect of rs2228570 (FokI) consistent with that detected in the present study $[20,21]$. An association with rs2228570 (FokI) was observed after adjustment for established risk factors including those used in the present study. This difference may be due to the tight relationship between $V D R$ protein function and the hormonal aspect of BC aetiology such as menarche, parity and menopause $[28,29]$.

In the case of MM, we did not observe any evidence of association with rs731236 (TaqI) (OR per allele $=1.08$,

Table 2: Genotype frequencies comparison between cases and controls in the four SNPs tested, in both BC and MM pathologies

\begin{tabular}{|c|c|c|c|c|c|c|c|c|c|c|}
\hline \multirow[b]{3}{*}{ SNP ID } & \multirow{3}{*}{$\begin{array}{l}\text { Statistical } \\
\text { model }\end{array}$} & \multirow{3}{*}{$\begin{array}{l}\text { Genotype } \\
\text { alleles }\end{array}$} & \multicolumn{4}{|c|}{ BREAST CANCER } & \multicolumn{4}{|c|}{ MELANOMA } \\
\hline & & & \multicolumn{2}{|c|}{ non-adjusted } & \multicolumn{2}{|c|}{ adjusted $\dagger$} & \multicolumn{2}{|c|}{ non-adjusted } & \multicolumn{2}{|c|}{ adjusted $\ddagger$} \\
\hline & & & $\begin{array}{c}\text { OR* } \\
(95 \% \mathrm{Cl})\end{array}$ & p-value & $\begin{array}{c}\mathrm{OR}^{*} \\
(95 \% \mathrm{Cl})\end{array}$ & p-value & $\begin{array}{c}\text { OR* } \\
(95 \% \mathrm{Cl})\end{array}$ & p-value & $\begin{array}{c}\text { OR* } \\
(95 \% \mathrm{Cl})\end{array}$ & p-value \\
\hline \multirow[t]{3}{*}{ rs 4516035} & Codominant & $\mathrm{CT}$ & $\begin{array}{c}1.20 \\
(0.92-1.56)\end{array}$ & 0.19 & $\begin{array}{c}1.15 \\
(0.83-1.58)\end{array}$ & 0.40 & $\begin{array}{c}1.08 \\
(0.73-1.60)\end{array}$ & 0.69 & $\begin{array}{c}1.17 \\
(0.70-1.96)\end{array}$ & 0.54 \\
\hline & & $\mathrm{CC}$ & $\begin{array}{c}1.16 \\
(0.82-1.65)\end{array}$ & 0.41 & $\begin{array}{c}0.97 \\
(0.63-1.49)\end{array}$ & 0.88 & $\begin{array}{c}1.5 \mathrm{I} \\
(0.90-2.53)\end{array}$ & 0.12 & $\begin{array}{c}1.79 \\
(0.91-3.53)\end{array}$ & 0.09 \\
\hline & $\begin{array}{l}\text { Per minor } \\
\text { allele }\end{array}$ & C- & $\begin{array}{c}1.09 \\
(0.92-1.29)\end{array}$ & 0.30 & $\begin{array}{c}1.01 \\
(0.82-1.25)\end{array}$ & 0.91 & $\begin{array}{c}1.20 \\
(0.94-1.55)\end{array}$ & 0.15 & $\begin{array}{c}1.31 \\
(0.94-1.81)\end{array}$ & 0.11 \\
\hline \multirow[t]{3}{*}{ rs2228570 } & Codominant & GA & $\begin{array}{c}1.14 \\
(0.88-1.47)\end{array}$ & 0.32 & $\begin{array}{c}1.26 \\
(0.89-1.66)\end{array}$ & 0.22 & $\begin{array}{c}1.09 \\
(0.75-1.57)\end{array}$ & 0.66 & $\begin{array}{c}1.23 \\
(0.76-2.01)\end{array}$ & 0.40 \\
\hline & & AA & $\begin{array}{c}I .4 \mathrm{I} \\
(0.96-2.08)\end{array}$ & 0.08 & $\begin{array}{c}1.65 \\
(1.02-2.65)\end{array}$ & 0.041 & $\begin{array}{c}0.69 \\
(0.38-1.25)\end{array}$ & 0.22 & $\begin{array}{c}1.23 \\
(0.55-2.73)\end{array}$ & 0.61 \\
\hline & $\begin{array}{l}\text { Per minor } \\
\text { allele }\end{array}$ & A- & $\begin{array}{c}1.17 \\
(0.98-1.40)\end{array}$ & 0.08 & $\begin{array}{c}1.26 \\
(1.02-1.57)\end{array}$ & 0.036 & $\begin{array}{c}0.91 \\
(0.70-1.19)\end{array}$ & 0.49 & $\begin{array}{c}1.15 \\
(0.8 I-1.64)\end{array}$ & 0.43 \\
\hline \multirow[t]{3}{*}{ rs731236 } & Codominant & $\mathrm{CT}$ & $\begin{array}{c}0.84 \\
(0.64-1.09)\end{array}$ & 0.19 & $\begin{array}{c}0.82 \\
(0.59-1.13)\end{array}$ & 0.22 & $\begin{array}{c}1.26 \\
(0.85-1.87)\end{array}$ & 0.25 & $\begin{array}{c}1.06 \\
(0.63-1.78)\end{array}$ & 0.81 \\
\hline & & $\mathrm{CC}$ & $\begin{array}{c}0.70 \\
(0.50-0.98)\end{array}$ & 0.040 & $\begin{array}{c}0.72 \\
(0.48-1.09)\end{array}$ & 0.13 & $\begin{array}{c}1.09 \\
(0.64-1.84)\end{array}$ & 0.76 & $\begin{array}{c}1.17 \\
(0.57-2.39)\end{array}$ & 0.66 \\
\hline & $\begin{array}{l}\text { Per minor } \\
\text { allele }\end{array}$ & C- & $\begin{array}{c}0.84 \\
(0.7 I-0.99)\end{array}$ & 0.034 & $\begin{array}{c}0.85 \\
(0.69-1.03)\end{array}$ & 0.10 & $\begin{array}{c}1.08 \\
(0.84-1.40)\end{array}$ & 0.55 & $\begin{array}{c}1.08 \\
(0.77-1.52)\end{array}$ & 0.66 \\
\hline \multirow[t]{3}{*}{ rs739837 } & Codominant & TG & $\begin{array}{c}0.96 \\
(0.72-1.27)\end{array}$ & 0.76 & $\begin{array}{c}0.96 \\
(0.69-1.35)\end{array}$ & 0.83 & $\begin{array}{c}0.89 \\
(0.59-1.36)\end{array}$ & 0.60 & $\begin{array}{c}0.64 \\
(0.36-1.13)\end{array}$ & 0.12 \\
\hline & & GG & $\begin{array}{c}1.03 \\
(0.74-1.44)\end{array}$ & 0.86 & $\begin{array}{c}1.30 \\
(0.87-1.96)\end{array}$ & 0.20 & $\begin{array}{c}0.82 \\
(0.50-1.36)\end{array}$ & 0.45 & $\begin{array}{c}0.69 \\
(0.35-1.38)\end{array}$ & 0.29 \\
\hline & $\begin{array}{l}\text { Per minor } \\
\text { allele }\end{array}$ & G- & $\begin{array}{c}1.01 \\
(0.86-1.20)\end{array}$ & 0.87 & $\begin{array}{c}1.13 \\
(0.92-1.38)\end{array}$ & 0.25 & $\begin{array}{c}0.91 \\
(0.71-1.17)\end{array}$ & 0.45 & $\begin{array}{c}0.83 \\
(0.59-1.16)\end{array}$ & 0.28 \\
\hline
\end{tabular}

*OR: Odds Ratio estimated under codominant and log-additive models; $\mathrm{Cl}$ : Confidence Interval.

†Adjusted for age at diagnosis, number of live births, age at menarche and menopause status.

¥Adjusted for eye colour, hair colour, skin colour, number of nevi, lentigines, and childhood sunburn.

Statistically significant results $(\mathrm{p}<0.05)$ indicated in bold. 
$95 \% \mathrm{CI}=0.84-1.40, \mathrm{p}=0.55)$ or rs2228570 (FokI) (OR per allele $=0.9195 \% \mathrm{CI}=0.70-1.19, \mathrm{p}=0.49)$. These results are consistent with the findings of smaller sample size studies $[13,30,31]$ although other studies reported a protective tendency of rs731236 (TaqI) [12,32]. Only two studies reported an association of rs2228570 (FokI) and $\mathrm{MM}$ risk in North-European populations, one of them being a larger sample size study $[12,32]$.

The rs731236 (TaqI) SNP is in linkage disequilibrium with other polymorphisms in the 3 ' extreme of the gene in Caucasian populations. Functional studies of these polymorphisms have evaluated their putative implication in the regulation of transcription, translation or RNA processing, but no consistent results were obtained [33]. However, functional studies of rs2228570 (FokI) have suggested a loss of the reported VDR benefits induced by the minor allele, due to its location in the first codon of the protein (Met1Thr). That is, the minor A allele appears to be associated with the use of an alternate start codon, which triggers a longer and less potent transcriptional activator protein form [7], which is consistent with it being associated with increased risk of BC. We did not observe evidence of association for any other SNP in BC or MM.

\section{Associations of VDR polymorphisms with personal, clinical and tumoral characteristics}

We assessed whether VDR SNPs were associated with various clinical and phenotypic characteristics using cases and controls combined. We tested for associations with tumour characteristics among cases only for each disease. Results are summarised in Table 3. The rare allele in the non-synonymous SNP rs2228570 (TaqI) appeared to be strongly associated with the absence of childhood sunburns (OR per allele $=0.65,95 \%$ CI 0.49-0.86, $\mathrm{p}=$ $0.003)$, and this was maintained among controls only (OR per allele $=0.63$ ). There was also weak evidence that it is associated with a prior diagnosis of $\mathrm{MM}$ in $\mathrm{MM}$ patients $(\mathrm{p}=0.060)$. We also observed marginally significant associations for the 3'utr SNP rs739837 (BglI) with fair skin colour $(\mathrm{p}=0.048)$ and with Fitzpatrick's phototype I/II (0.070). Finally, the VDR promoter SNP rs4516035 was associated with tumours located in the head-neck or trunk ( $\mathrm{p}=0.020)$. No other associations were observed for BC or MM. Although we did not detect a significant effect of VDR SNPs directly on MM, the associations identified with MM phenotypic characteristics suggest that VDR SNPs may modulate MM susceptibility.

\section{Further considerations}

The strength of our study is the ability to control for the many established risk factors for $\mathrm{BC}$ and $\mathrm{MM}$, although we recognize that there was potential for misclassification of phenotypic characteristics due to the subjective nature of the phenotypic attributes considered. Controls participated on a volunteer basis which may have introduced some selection bias. However, the fact that they were frequency matched to cases on age and sex for melanoma and that breast cancer controls were selected so that their age range was comparable to that of cases and that the variable of primary interest was genetic would have kept such bias to a minimum. It should be noted that, the sample size of both studies was relatively limited and so associations can not be ruled out for rs731236 (TaqI), and rs2228570 (FokI), particularly in MM. The association of rs731236 (TaqI) and BC, was not statistically significant under a multivariate model. However, the estimated relative risk did not change substantially, indicating that the increase in p-value was due to the reduced sample size (with available covariate data), rather than due to confounding. Finally, conclusions are based on nominal pvalues at 5\% statistical significance and therefore require replication in independent studies.

\section{Conclusion}

$\mathrm{BC}$ and MM tumour pathologies may be influenced by the effect of variation in vitamin $\mathrm{D}$ intake through diet and sun exposure, together with VDR polymorphisms. Therefore, in a sunny region such as Spain, the effect of VDR polymorphisms on cancer risk may be more apparent than in other Caucasian populations. The results obtained in this study add to the evidence for a role of VDR as an important mediator in the development of cancer. We found evidence of association with $\mathrm{BC}$ for the non-synonymous variant rs2228570 (FokI), and for the synonymous SNP rs731236 (TaqI). These findings require replication in large samples and the role of these variants needs to be clarified by functional studies. We have also reported several associations among VDR SNPs and phenotypic risk factors that influence MM susceptibility, indicating their potential effect in disease development. The characterization of these and other polymorphisms in the VDR gene may help to better understand the aetiology and development of cancer, and to define risk groups to better target prevention strategies.

\section{Abbreviations}

VDR: Vitamin D receptor; BC: Breast cancer; MM: Malignant melanoma; SNP: Single nucleotide polymorphism; OR: Odds ratio; UV: Ultraviolet; DNA: Deoxyribonucleic acid; MAF: Minor alelle frequency; HWE: Hardy-Weinberg equilibrium; CIs: Confidence Intervals

\section{Competing interests}

The authors declare that they have no competing interests.

\section{Authors' contributions}

EB and LPF participated in the design of the study, acquisition of data, genotyping, analysis and interpretation of data, performed the statistical analysis and drafted the 
Table 3: Personal, clinical and tumoral phenotypic characteristics comparison from both BC and MM pathologies in the four SNPs tested

\begin{tabular}{|c|c|c|c|c|c|c|c|c|c|}
\hline Tumour & & rs45 I6035 & & rs2228570 & & rs731236 & & rs739837 & \\
\hline Type & Characteristic & OR* $(95 \% \mathrm{Cl})$ & p-value & OR* $(95 \% \mathrm{Cl})$ & p-value & OR* $(95 \% \mathrm{Cl})$ & p-value & OR* $(95 \% \mathrm{Cl})$ & p-value \\
\hline
\end{tabular}

\section{BREAST CANCER}

\begin{tabular}{|c|c|c|c|c|c|c|c|c|}
\hline Metastasis $\ddagger$ & $0.53(0.25-1.11)$ & 0.09 & $1.00(0.51-1.96)$ & 0.99 & $1.20(0.63-2.27)$ & 0.58 & I.II (0.57-2.17) & 0.75 \\
\hline $\begin{array}{l}\text { Tumor histology } \\
\text { (Invasive) })^{\ddagger}\end{array}$ & $0.87(0.57-1.32)$ & 0.51 & $0.83(0.54-1.28)$ & 0.40 & $1.10(0.72-1.69)$ & 0.66 & $0.75(0.49-1.15)$ & 0.19 \\
\hline $\begin{array}{l}\text { Tumor grade } \\
(\text { Grade }>I)^{\ddagger}\end{array}$ & $0.93(0.67-1.30)$ & 0.68 & $1.19(0.84-1.68)$ & 0.33 & $1.22(0.87-1.70)$ & 0.26 & $0.76(0.54-1.05)$ & 0.09 \\
\hline $\begin{array}{c}\text { Tumor size }(>2 \\
\mathrm{cm})^{\ddagger}\end{array}$ & $1.02(0.77-1.35)$ & 0.92 & $0.98(0.73-1.30)$ & 0.88 & $1.14(0.86-1.51)$ & 0.37 & $0.81(0.61-1.08)$ & 0.15 \\
\hline $\begin{array}{c}\text { Nodal } \\
\text { involvement } \ddagger\end{array}$ & $0.93(0.70-1.23)$ & 0.61 & $0.95(0.7 \mid-1.27)$ & 0.72 & $0.94(0.7 \mid-1.25)$ & 0.69 & $1.09(0.82-1.45)$ & 0.54 \\
\hline ER positive $\ddagger$ & $0.96(0.66-1.4 I)$ & 0.85 & $1.24(0.84-1.84)$ & 0.28 & $1.31(0.90-1.90)$ & 0.16 & $1.02(0.7 \mid-1.46)$ & 0.91 \\
\hline PR positive $\ddagger$ & $0.92(0.67-1.26)$ & 0.60 & $1.12(0.80-1.55)$ & 0.51 & $0.91(0.67-1.24)$ & 0.56 & $1.12(0.83-1.5 \mathrm{I})$ & 0.48 \\
\hline
\end{tabular}

\section{MELANOMA}

\begin{tabular}{|c|c|c|c|c|c|c|c|c|}
\hline $\begin{array}{l}\text { Light Eye } \\
\text { Colour }^{+}\end{array}$ & $1.03(0.79-1.34)$ & 0.82 & $0.91(0.69-1.21)$ & 0.52 & $0.92(0.70-1.21)$ & 0.56 & $1.06(0.81-1.39)$ & 0.64 \\
\hline $\begin{array}{l}\text { Blond } / \text { Red Hair } \\
\text { Colour }^{+}\end{array}$ & $0.99(0.7 \mathrm{I}-\mathrm{I} .40)$ & 0.99 & $0.78(0.55-1.13)$ & 0.19 & I.02 (0.73-I.44) & 0.89 & $1.45(0.89-1.74)$ & 0.20 \\
\hline $\begin{array}{l}\text { Fair Skin } \\
\text { Colour }\end{array}$ & $0.97(0.75-1.26)$ & 0.83 & I.08 (0.82-I.42) & 0.57 & $0.86(0.66-1.12)$ & 0.25 & $\begin{array}{c}1.31 \\
(1.00-1.70)\end{array}$ & 0.048 \\
\hline$\underset{50^{+}}{\mathrm{N}^{\circ} \text { of } \mathrm{Nevi}}=$ & $0.97(0.66-1.40)$ & 0.85 & $1.00(0.67-1.49)$ & 0.99 & $1.06(0.72-1.54)$ & 0.77 & $1.34(0.90-1.97)$ & 0.15 \\
\hline $\begin{array}{l}\text { Presence of } \\
\text { Lentigines }^{+}\end{array}$ & I.03 (0.79-I.34) & 0.84 & $0.79(0.59-1.05)$ & 0.11 & $1.20(0.91-1.58)$ & 0.21 & $0.90(0.69-1.18)$ & 0.45 \\
\hline $\begin{array}{l}\text { Presence of } \\
\text { Childhood } \\
\text { Sunburns }\end{array}$ & $1.12(0.87-1.45)$ & 0.39 & $\begin{array}{c}0.65 \\
(0.49-0.86)\end{array}$ & 0.003 & $1.10(0.84-1.43)$ & 0.49 & $0.91(0.70-1.19)$ & 0.50 \\
\hline Other MM $\ddagger$ & $1.26(0.52-3.03)$ & 0.61 & $2.43(0.95-6.19)$ & 0.060 & I.83 (0.73-4.56) & 0.19 & $0.70(0.26-1.85)$ & 0.47 \\
\hline $\begin{array}{l}\text { Fitzpatrick's } \\
\text { photoype I/II }\end{array}$ & $0.74(0.51-1.09)$ & 0.13 & $0.85(0.63-1.46)$ & 0.89 & $0.91(0.62-1.34)$ & 0.63 & $1.43(0.97-2.12)$ & 0.070 \\
\hline $\begin{array}{c}\text { Tumor Location } \\
\text { (Head/Neck/ } \\
\text { Trunk) })^{\ddagger}\end{array}$ & $\begin{array}{c}1.54 \\
(1.08-2.20)\end{array}$ & 0.020 & $1.16(0.79-1.72)$ & 0.45 & $1.16(0.81-1.65)$ & 0.42 & $1.17(0.82-1.67)$ & 0.38 \\
\hline $\begin{array}{c}\text { Breslow Index } \\
(\mathrm{T} 2 / \mathrm{T} 3 / \mathrm{T} 4)^{\ddagger}\end{array}$ & I.04 (0.72-I.5I) & 0.82 & $1.20(0.80-1.79)$ & 0.38 & $0.84(0.57-1.24)$ & 0.38 & 1.01 (0.69-1.47) & 0.96 \\
\hline
\end{tabular}

*OR: Odds Ratio per minor allele; Cl: Confidence Interval, unadjusted p-values.

+Cases and controls pooled for each variable.

‡Cases only considered.

Statistically significant results $(p<0.05)$ indicated in bold.

manuscript. RLM performed the interpretation of data, the statistical analysis and drafted the manuscript. GP has been involved in the acquisition, designing sample database used for the study and interpretation of data. ES, UF, MF, JAA, MM, JIA, PZ, MB and PL participated in patient enrolment and patient phenotypic classification and the acquisition of clinical data. JB have been involved in revising the manuscript and in given final approval of the version to be published. GR participated in the design of the study, analysis and interpretation of data, revising the manuscript and in given final approval of the version to be published.
The manuscript has been seen and approved by all listed authors. E Barroso and LP Fernandez contributed equally to this work.

\section{Additional material}

\section{Additional file 1}

Personal, clinical and tumoral phenotypic characteristics in cases and controls in BC. The data provided represent the personal, clinical and tumoral phenotypic characterization of BC samples used in the study. Click here for file

[http://www.biomedcentral.com/content/supplementary/14712407-8-385-S1.doc] 


\section{Additional file 2}

Personal, clinical and tumoral phenotypic characteristics in cases and controls in MM. The data provided represent the personal, clinical and tumoral phenotypic characterization of MM samples used in the study. Click here for file

[http://www.biomedcentral.com/content/supplementary/14712407-8-385-S2.doc]

\section{Acknowledgements}

This study was supported by grants BFI2003-03852 and SAF2007-65542C02-0I from the Ministerio de Educación y Ciencia (MEC) and Fundación Mútua Madrileña, Spain (GR). EB is funded by the Comunidad Autónoma de Madrid and LPF is funded by the Ministerio de Sanidad y Consumo under a grant form the Fondo de Investigación Sanitaria FI05/00918. We would like to thank Álvaro Ruibal (University Hospital, Santiago de Compostela), and Santiago Palacios (Instituto Palacios, Madrid), Mariano Casado, Angel Pizarro and Matias Mayor (Hospital La Paz), Angeles de la Riva Grandal (Hospital Ramón y Cajal) and staff at the Hospital Gregorio Marañon and Madrid College of Lawyers for the access to samples of cases and controls. We would also like to thank Fátima Mercadillo, Alicia Barroso, Victoria Fernández and Rocío Letón for their expert technical skills.

\section{References}

I. Trang HM, Cole DE, Rubin LA, Pierratos A, Siu S, Vieth R: Evidence that vitamin D3 increases serum 25-hydroxyvitamin $D$ more efficiently than does vitamin D2. Am J Clin Nutr 1998, 68(4):854-858.

2. Jurutka PW, Whitfield GK, Hsieh JC, Thompson PD, Haussler CA, Haussler MR: Molecular nature of the vitamin $D$ receptor and its role in regulation of gene expression. Rev Endocr Metab Disord 200I, 2(2):203-2I6.

3. Deeb KK, Trump DL, Johnson CS: Vitamin D signalling pathways in cancer: potential for anticancer therapeutics. Nat Rev Cancer 2007, 7(9):684-700.

4. Bikle DD, Oda $Y$, Xie Z: Vitamin $D$ and skin cancer: a problem in gene regulation. J Steroid Biochem Mol Biol 2005, 97(I-2):83-9I.

5. Cui Y, Rohan TE: Vitamin D, calcium, and breast cancer risk: a review. Cancer Epidemiol Biomarkers Prev 2006, I 5(8): I 427-I 437.

6. Guy M, Lowe LC, Bretherton-Watt D, Mansi JL, Peckitt C, Bliss J, Wilson RG, Thomas $\mathrm{V}$, Colston KW: Vitamin D receptor gene polymorphisms and breast cancer risk. Clin Cancer Res 2004, I 0( I 6):5472-548I.

7. Arai H, Miyamoto K, Taketani $\mathrm{Y}$, Yamamoto $\mathrm{H}$, lemori $\mathrm{Y}$, Morita $\mathrm{K}$, Tonai T, Nishisho T, Mori S, Takeda E: A vitamin D receptor gene polymorphism in the translation initiation codon: effect on protein activity and relation to bone mineral density in Japanese women. J Bone Miner Res 1997, I 2(6):915-92।.

8. Colin EM, Weel AE, Uitterlinden AG, Buurman CJ, Birkenhager JC, Pols HA, van Leeuwen JP: Consequences of vitamin D receptor gene polymorphisms for growth inhibition of cultured human peripheral blood mononuclear cells by I, 25-dihydroxyvitamin D3. Clin Endocrinol (Oxf) 2000, 52(2):2। I-2। 6.

9. McCullough ML, Stevens VL, Diver WR, Feigelson HS, Rodriguez C, Bostick RM, Thun MJ, Calle EE: Vitamin D pathway gene polymorphisms, diet, and risk of postmenopausal breast cancer: a nested case-control study. Breast Cancer Res 2007, 9(I):R9.

10. Trabert B, Malone KE, Daling JR, Doody DR, Bernstein L, Ursin G, Marchbanks PA, Strom BL, Humphrey MC, Ostrander EA: Vitamin $D$ receptor polymorphisms and breast cancer risk in a large population-based case-control study of Caucasian and African-American women. Breast Cancer Res 2007, 9(6):R84.

II. Abbas S, Nieters A, Linseisen J, Slanger T, Kropp S, Mutschelknauss EJ, Flesch-Janys D, Chang-Claude J: Vitamin D receptor gene polymorphisms and haplotypes and postmenopausal breast cancer risk. Breast Cancer Res 2008, I0(2):R3I.

12. Hutchinson PE, Osborne JE, Lear JT, Smith AG, Bowers PW, Morris $\mathrm{PN}$, Jones PW, York C, Strange RC, Fryer AA: Vitamin D receptor polymorphisms are associated with altered prognosis in patients with malignant melanoma. Clin Cancer Res 2000, 6(2):498-504.

13. Santonocito C, Capizzi R, Concolino P, Lavieri MM, Paradisi A Gentileschi S, Torti E, Rutella S, Rocchetti S, Di Carlo A, et al.: Association between cutaneous melanoma, Breslow thickness and vitamin D receptor Bsml polymorphism. Br J Dermatol 2007, I 56(2):277-282.

14. Den Outer PN, Slaper H, Tax RB: UV radiation in the Netherlands: Assessing long-term variability and trends in relation to ozone and vlouds. Journal of geophysical research 2005, I 1 0:D02203. 0220I-022II

15. Marin MJ, Sola Y, Tena F, Utrillas MP, Campmany E, de Cabo X, Lorente J, Martinez-Lozano JA: The UV index on the Spanish Mediterranean coast. Photochemistry and photobiology $8 \mathrm{I}(3): 659-665$.

16. Fernandez L, Milne R, Bravo J, Lopez J, Aviles J, Longo M, Benitez J, Lazaro P, Ribas G: MCIR: three novel variants identified in a malignant melanoma association study in the Spanish population. Carcinogenesis 2007, 28(8): 1659-1664

17. Fernandez LP, Milne RL, Pita G, Aviles JA, Lazaro P, Benitez J, Ribas G: SLC45A2: a novel malignant melanoma-associated gene. Hum Mutat 2008, 29(9): I |6I-I I67.

18. Kessler HH, Muhlbauer G, Stelzl E, Daghofer E, Santner BI, Marth E: Fully automated nucleic acid extraction: MagNA Pure LC. Clin Chem 200I, 47(6): I I24-I I 26.

19. Barroso E, Milne RL, Fernandez LP, Zamora P, Arias JI, Benitez J, Ribas G: FANCD2 associated with sporadic breast cancer risk. Carcinogenesis 2006, 27(9): 1930-1937.

20. Chen WY, Bertone-Johnson ER, Hunter DJ, Willett WC, Hankinson SE: Associations between polymorphisms in the vitamin $D$ receptor and breast cancer risk. Cancer Epidemiol Biomarkers Prev 2005, I 4( I 0):2335-2339.

21. Gapska P, Scott RJ, Serrano-Fernandez P, Huzarski T, Byrski T, Kladny J, Gronwald J, Gorski B, Cybulski C, Lubinski J, et al:: Vitamin D receptor variants and breast cancer risk in the Polish population. Breast Cancer Res Treat 2008.

22. Hou MF, Tien YC, Lin GT, Chen CJ, Liu CS, Lin SY, Huang TJ: Association of vitamin $D$ receptor gene polymorphism with sporadic breast cancer in Taiwanese patients. Breast Cancer Res Treat 2002, 74(I): I-7.

23. Buyru N, Tezol A, Yosunkaya-Fenerci E, Dalay N: Vitamin D receptor gene polymorphisms in breast cancer. Exp Mol Med 2003, 35(6):550-555.

24. Curran JE, Vaughan T, Lea RA, Weinstein SR, Morrison NA, Griffiths $L R$ : Association of A vitamin $D$ receptor polymorphism with sporadic breast cancer development. Int J Cancer 1999, 83(6):723-726

25. Bretherton-Watt D, Given-Wilson R, Mansi JL, Thomas V, Carter N, Colston KW: Vitamin D receptor gene polymorphisms are associated with breast cancer risk in a UK Caucasian population. Br J Cancer 200 I, 85(2): I7I-I75.

26. Ingles SA, Garcia DG, Wang W, Nieters A, Henderson BE, Kolonel LN, Haile RW, Coetzee GA: Vitamin D receptor genotype and breast cancer in Latinas (United States). Cancer Causes Control 2000, II (I):25-30

27. John EM, Schwartz GG, Koo J, Wang W, Ingles SA: Sun exposure, vitamin $D$ receptor gene polymorphisms, and breast cancer risk in a multiethnic population. Am J Epidemiol 2007, 166(12): | 409-1419.

28. Gilad LA, Bresler T, Gnainsky J, Smirnoff P, Schwartz B: Regulation of vitamin $D$ receptor expression via estrogen-induced activation of the ERK I/2 signaling pathway in colon and breast cancer cells. J Endocrinol 2005, I 85(3):577-592.

29. Gilad LA, Schwartz B: Association of estrogen receptor beta with plasma-membrane caveola components: implication in control of vitamin D receptor. I Mol Endocrinol 2007, 38(6):603-618.

30. Halsall JA, Osborne JE, Potter L, Pringle JH, Hutchinson PE: A novel polymorphism in the IA promoter region of the vitamin $D$ receptor is associated with altered susceptibilty and prognosis in malignant melanoma. Br J Cancer 2004, 9 I (4):765-770.

31. Han J, GA Colditz, DJ Hunter: Polymorphisms in the MTHFR and VDR genes and skin cancer risk. Carcinogenesis 2007, 28:390-7. 
32. Li C, Z Liu, LE Wang, JE Gershenwald, JE Lee, VG Prieto, et al.: Haplotype and genotypes of the VDR gene and cutaneous melanoma risk in non-Hispanic whites in Texas: a case-control study. International Journal of Cancer 2008, I 22:2077-84.

33. Durrin LK, Haile RW, Ingles SA, Coetzee GA: Vitamin D receptor 3 '-untranslated region polymorphisms: lack of effect on mRNA stability. Biochim Biophys Acta 1999, I 453(3):3 I I-320.

\section{Pre-publication history}

The pre-publication history for this paper can be accessed here:

http://www.biomedcentral.com/1471-2407/8/385/pre pub

Publish with Bio Med Central and every scientist can read your work free of charge

"BioMed Central will be the most significant development for disseminating the results of biomedical research in our lifetime. " Sir Paul Nurse, Cancer Research UK

Your research papers will be:

- available free of charge to the entire biomedical community

- peer reviewed and published immediately upon acceptance

- cited in PubMed and archived on PubMed Central

- yours - you keep the copyright

Submit your manuscript here:

http://www.biomedcentral.com/info/publishing_adv.asp 